during the Dashnak hunt maintained a pragmatic outlook in which the tsar stood as the only savior of the sultan's besieged minorities. The celebrated poet Hovhannes Tumanian insisted that, "historical circumstances demonstrate that the Armenian people had to be with the Russian people and must tie all their hopes to the success of the Russian state" (152). On the eve of the Great War, "the friction between the Dashnaks and Russia was fading as the former channeled their energies toward the Ottoman Armenians" (180), tsarist authorities permitted small shipments of weapons across the Russo-Ottoman border for the purposes of Western Armenian "selfdefense," and Nicholas II pardoned all of the remaining convicts from the Dashnak trials of 1908-12.

A skilled storyteller, Önol must be commended for presenting a complex chapter of Russian, Armenian, and Caucasian history in an accessible, persuasive manner. The book's narrow chronological scope, moreover, affords it a level of detail that is elusive in most studies of this or related topics.

STEPHEN B. RIEGG

Texas A\&M University

\title{
Vladimir Burtsev and the Struggle for a Free Russia: A Revolutionary in the Time of Tsarism and Bolshevism. By Robert Henderson. London: Bloomsbury Aca- demic, 2017. xii, 353 pp. Appendix. Notes. Bibliography. Index. Illustration. Pho- tographs. $\$ 50.99$, hard bound.
}

doi: 10.1017/slr.2018.339

With this book, Robert Henderson adds his name to the list of recent historians who have attempted to illuminate the history of imperial Russia through biography, often of lesser known figures. Vladimir L'vovich Burtsev (1862-1942) is familiar to historians of the Russian revolutionary movement as the compiler in 1896 of the first chronicle of that movement (Za sto let) and the founder in 1906 of the legendary journal Byloe, whose first number went through three separate print runs of ten thousand each, and still stands as an essential document of the times. He was also the person responsible for exposing the Azef, the notorious police agent who had penetrated the inner circles of the Socialist Revolutionary Party, as well as Malinovsky, a figure close to Lenin in Social Democratic circles. Yet he is hardly a household word, even with historians of Russia in general.

In his own time, Burtsev was celebrated in London in the 1890 s as a persecuted but noble exile and opponent of the tsarist autocracy, while in Russia he "was now so feared by the police that his name had become synonymous with that of a "dangerous terrorist"” (130). In his early years Burtsev argued that "kill the tsar and everything will fall in place," (83) and refused to join the SR Party when it was established because it was not "terroristic enough" (88). Paradoxically, as the author points out, Burtsev was actually an armchair revolutionary-although the author of this book never uses the term-and while for the tsarist authorities his "name had become synonymous with that of a 'dangerous terrorist"' he was considered by his comrades "to be too meek and gentle to mix into current terrorist plotting, was never admitted into revolutionary councils and indeed was never involved in any assassination conspiracies" (130). Later in life, at great peril to himself, Burtsev returned home from exile with the outbreak of World War I, became a prominent "defensist" standing with the monarchy in the war effort and later siding with Lavr Kornilov in August 1917 as well as Pyotr Wrangel in the last acts of the bloody civil war. From the start, he too found the SD Party to be an "abomination" (107) and loathed Vladimir Lenin (neither did he get along with Aleksandr Kerenskii). He spent his last years once again in penurious 
exile and quarreling with all sides. Despite these tergiversations, throughout his life he insisted that he was an inveterate socialist and called for a unified movement that superseded all party affiliation.

In person, Burtsev was a slight, mild-mannered, disheveled and hopelessly impractical person incapable of dealing with money. He was never happier than when he was sitting in the British Museum pursuing his studies, which involved not only chronicling the revolutionary movement, but writing about literature, working on a study of Shakespeare for a Russian audience, and even publishing newly-edited and "corrected" versions of the works of Aleksandr Pushkin, Ivan Turgenev, Ivan Goncharov and others. Above all, he was a journalist at heart. While Henderson acknowledges that it is difficult to pin down this personality and quotes liberally from the contradictory perceptions of him recorded by his contemporaries, he clearly states that his was a "remarkable life" (3) and conveys his empathy for Burtsev and his admiration for the "Don Quixote," "Sherlock Holmes," or even "Nestor" of the Russian revolutionary movement, as he was variously labelled at the time.

The prose in this work is lucid and generally engaging, and specialists will find useful his careful treatment of a number of controversial issues such as the Asef affair, for which his diligent work in the British National Archives and the British Museum Archives, GARF, RGASPI, the Institute of International Social History in Amsterdam, the National Archives in Paris, and the Hoover Institution yielded numerous new insights and nuances. The story of the journal Byloe is little known and given fascinating treatment here. Even those familiar with the general contours of Burtsev's life will find his treatment of the "black hole" period of the 1890's, and his activities during World War I, will find much that is new and significant. Especially eye-catching is the depiction of the diligence, thoroughness, and unceasing efforts of the Foreign Agency of the Russian Department of Police, its close ties with Scotland Yard and the French police directorate. It is a surprise to learn, when it comes to the infamous conversion of the terrorist Lev Tikhomirov to monarchism in 1888, that this act was at least partially brought about by a sustained campaign of psychological warfare conducted by Petr Rachkovsky, head of the Russian police agency: letters went missing, money transfers were held up, doctors refused to treat his child, scurrilous telegraphs were sent to friends under his name, all over a lengthy time period, reducing him, in the eyes of his comrades, to "an ordinary scoundrel" (24). In the words of Rachkovsky, Tikhomirov "has been driven, literally to madness which in turn has led to a total mental and physical collapse" (24-25).

Given the host of names involved in this story, readers not familiar with revolutionaries such as Stepniak, Lazerev, Volkhovskii, and Shishko, never mind the police chief Lopukhin and other autocratic officials, will find it sometimes hard to keep track, and a glossary of names would have been welcome. At times, too, one has to dig to be sure exactly what year is being discussed. Finally, at times Henderson seems to adopt the descriptors Burtsev uses to label opponents as his own (for example "traitor") when a bit more critical difference might have been advisable. Henderson never successfully resolves the apparent contradiction in Burtsev's personality and in how he was viewed by others, nor do we learn how it was that police agencies in several countries came to mistakenly identify him as a bomb-throwing fanatic. But such quibbles are minor and do not detract from the worth of this admirable and engaging biography. Above all, given our present concerns about terrorism as an international phenomenon, such a work reminds us that that the label needs to be described with a sensitivity to historical context and an awareness of how the meaning of words can change over time. 